\title{
A Study on the Well-being and the Leisure Satisfaction of Zhuhai Residents
}

\author{
Bingxian Liu \\ Tourism College \\ Zhuhai College of Jilin University \\ Zhuhai, China
}

\author{
$\mathrm{Li} \mathrm{Li}$ \\ Foreign languages College \\ Zhuhai College of Jilin University \\ Zhuhai, China
}

\begin{abstract}
The Chinese government regards residents' happiness as one of the major administrative achievements, which is also individuals' final goal. Based on the research case-Zhuhai, it is supposed that there exists high relativity between leisure satisfaction and happiness, which is proved through the questionnaire survey and the statistical test. To compare different resident groups' attitudes towards leisure satisfaction, the research, taking demographic characteristics into account, meanwhile indicates that variables as gender, age, salary greatly influence leisure satisfaction, compared with such factors as marital status, education, family structure, and residence and so on.
\end{abstract}

Keywords-leisure satisfaction; well-being/happiness; Zhuhai resident

\section{INTRODUCTION}

The research of happiness is a traditional topic discussed by philosophy, psychology, sociology, ethnics and economics, which is the final goal of all generations and all different people. The sense of happiness is decided by many factors, including not only money, income, wealth, individuality and personal elements, but also wide-ranging social backgrounds. The acquisition of happiness is closely related to leisure satisfaction, which also fits the change of Chinese government's administrative idea that the focus on the increase of GDP is switched to the humanistic concern of happiness. "For the happiness of the Chinese people", this idea runs through the Nineteenth Congress Report made by President Xi Jinping, and The Outline of National Tourism and Leisure, issued by the State Council of China, views the humanistic concern as the administrative idea, aims to enhance the life quality of people, in order to increase the national happiness index. In January 2011, the Ninth Plenary Session of the Sixth Session of Zhuhai Municipal Party Committee put forward the development goal "to take the lead in transformation and upgrading, and to develop the happy Zhuhai". The policy concentrates on enhancing Zhuhai people's sense of welfare, sense of security, sense of justice, sense of belongingness and sense of pride.

According to Aristotle, the pioneer in the study of happiness, happiness is a final end or goal that encompasses the totality of one's life and defined happiness to be "an activity of the soul in accordance with virtue". In modern times, studies on happiness or well-being emerged in 1950s by scholars of many disciplines and various words concerning well-being have been adopted owing to different interpretations and perspectives of happiness, such as happiness, pleasure, subjective well-being, psychological well-being, perceived wellness, life satisfaction and so on[1] [6].

The study of leisure satisfaction starts from 1980s, which is served to measure specific leisure quality and individual leisure quality. Leisure satisfaction is a satisfaction dimension which is included in life satisfaction and social satisfaction. Beard \& Ragheb defined leisure satisfaction as positive satisfaction or emotions that an individual shows, achieves or obtains due to participation in leisure activities [7]. Leisure satisfaction indicates the extent to which the individual is satisfied with leisure experiences. Satisfaction of positive feelings is achieved by satisfying individual needs [8]. Measuring whether the individuals gain the desired benefit from the leisure activities they take part in, whether they can satisfy their needs, and whether they are happy to participate in these activities can provide important data to take measures to make them happier and more satisfied and to develop leisure activities provided in line with their satisfaction level and even to enhance activity options [9].

This study aims to answer three questions:(1) Is there any relativity between leisure satisfaction and happiness? If yes, how relevant is it?(2) How much is the Zhuhai resident's leisure satisfaction?(3) Is there any difference among different groups?

\section{RESEARCH DESIGN}

\section{A. Case Selection}

As one of China's first special economic zones, Zhuhai is in the southwest of the Pearl River estuary in Guangdong Province, with Hong Kong in the east, Macao in the south, and Xinhui, Taishan and Zhongshan in the west.

Till the end of 2015, the city's total area stands at 1,724 sq $\mathrm{km}$ of land. It recorded a population of 1.63 million, among which household registration population is 1.09 million. The proportion of urban residents is $87.85 \%$. Zhuhai has three districts (Xiangzhou, Doumen and Jinwan) and five economic zones (Gaolan Port Economic, Zhuhai Hi-Tech, Zhuhai Free Trade, Hengqin FTZ, and Zhuhai Wanshan 
Marine Development Experimental). Among these, Xiangzhou District is the downtown of the city, with the most population and developed urbanization level; while Doumen District and Jinwan District can be viewed as the representatives of suburban, with the small size of population and low urbanization.

\section{B. Questionnaire Design and Distribution}

The Questionnaire of Zhuhai Citizen's Leisure Satisfaction is designed from two parts. One is the research of Zhuhai Citizen's Leisure Satisfaction. The question whether there is any relativity between leisure satisfaction and happiness is firstly raised, and then The Leisure Satisfaction Scale (LSS) put forward by Beard and Ragheb [7]is adopted to measure the Zhuhai residents' leisure satisfaction. LSS consists of six dimensions (psychological, educational, social, relaxational, physiological and aesthetic) and 24 questions. These questions, according to 5-point Likert Scale, are rated and valued from "total disapproval" to "total satisfaction." The other is about basic background of the inquired, including gender, age, residence, registered residence and income.

400 questionnaires were conducted in the Coastal Park in Xiangzhou District, the Gold Coastal Culture and Art Center in Jinwan District, and the Leisure Park of Huafa Water County in Doumen District between December 4-8 in 2017. Among these questionnaires, 200 were distributed in the Coastal Park, and 100 respectively in the latter two locations. Then 345 questionnaires were effectively recalled.

\section{RESULT OF THE RESEARCH}

\section{A. The Research of the Demographic Characteristics of the Sample}

As the "Table I" shows, the research sample has following features: female is more than male; the age gathers between 26-64; elementary education and high education are half and half; salary concentrates on 2500-8000; and the three people of the family is in the majority.

TABLE I. POPUlation Structure OF SAMPLE

\begin{tabular}{|c|l|l|l|}
\hline $\begin{array}{c}\text { Demographic } \\
\text { Characteristics }\end{array}$ & Category & $\begin{array}{c}\text { Number of } \\
\text { person }\end{array}$ & percentage \\
\hline \multirow{4}{*}{ Gender } & Male & 156 & 45.2 \\
\cline { 2 - 4 } & Female & 189 & 54.8 \\
\hline \multirow{4}{*}{ Martial Status } & Married & 257 & 74.5 \\
\cline { 2 - 4 } & Single & 88 & 25.5 \\
\hline \multirow{5}{*}{ Age } & $\leq 18$ & 21 & 6.1 \\
\cline { 2 - 4 } & $19-25$ & 30 & 8.7 \\
\cline { 2 - 4 } & $26-44$ & 127 & 36.8 \\
\cline { 2 - 4 } & $45-64$ & 105 & 30.4 \\
\cline { 2 - 4 } & $\geq 65$ & 62 & 17.8 \\
\hline \multirow{5}{*}{ Residence } & Xiangzhou & 166 & 83 \\
\cline { 2 - 4 } & Jinwan & 91 & 91 \\
\cline { 2 - 4 } & Doumen & 88 & 32.4 \\
\hline Educational Status & $\leq$ Primary & 60 & 14.8 \\
\cline { 2 - 4 } & Middle School & 123 & \\
\cline { 2 - 4 } & College & 111 & 35.6 \\
\cline { 2 - 4 } & $\geq$ Postgraduate & 51 & 32.2 \\
\hline
\end{tabular}

\begin{tabular}{|c|l|l|l|}
\hline $\begin{array}{c}\text { Demographic } \\
\text { Characteristics }\end{array}$ & \multicolumn{1}{|c|}{ Category } & $\begin{array}{c}\text { Number of } \\
\text { person }\end{array}$ & percentage \\
\hline \multirow{4}{*}{ Family Size } & Single & 14 & 4.0 \\
\cline { 2 - 4 } & Two & 40 & 11.6 \\
\cline { 2 - 4 } & Three & 108 & 31.3 \\
\cline { 2 - 4 } & Four & 95 & 27.5 \\
\cline { 2 - 4 } & $\geq$ Five & 88 & 25.5 \\
\hline Income & $\leq 2500$ (RMB yuan) & 42 & 12.2 \\
\cline { 2 - 4 } & $2501-5000$ & 99 & 28.7 \\
\cline { 2 - 4 } & $5001-8000$ & 98 & 28.4 \\
\cline { 2 - 4 } & $8001-15000$ & 90 & 26.1 \\
\cline { 2 - 4 } & $15001-30000$ & 13 & 3.8 \\
\cline { 2 - 4 } & $\geq 30001$ & 3 & 0.8 \\
\hline
\end{tabular}

B. The Relationship Between Leisure Satisfaction and Wellbeing

Through two questions, one about "When participating in leisure activities, I feel very happy", the other about "When I participate in leisure activities, the sense of well-being is spontaneous in heart", the relativity between citizen's leisure satisfaction and happiness is measured. According to 5-point Likert Scale, the research indicates the high scores of the two questions, and 4.6 on average. The average score of the first question is 4.66, and the second is 4.52. Therefore, the conclusion that the relativity between leisure satisfaction and happiness is highly related can be safely achieved. It also means that people's happiness is directly influenced by their leisure satisfaction which, instead of indexes, can even measure happiness.

\section{Overall Condition of Zhuhai Residents' Leisure Satisfaction}

Based on the statistical analysis of the description of the result of Zhuhai residents' leisure satisfaction, the table 2 shows the results: (1) The overall of Zhuhai residents' leisure satisfaction is high, and the average satisfaction of the six dimensions is 3.94, which indicates that most Zhuhai citizen hold positive attitudes towards leisure activities, through which the active influence on psychology, education and so on is acquired. (2) According to six dimensions, the evaluation of psychology and relaxation are high, compared to other four dimensions, such as education, social contact, physiology and aesthetics. The result proves that most people fully recognizes the value of leisure activities as means to psychology and relaxation; meanwhile, others need to be improved, which points out the way to the construction of leisure facilities and the development of leisure activities in the future. 
TABLE II. EVALUATION VALUE OF DimENSIONS ON LEISURE SATISFACTION

\begin{tabular}{|c|c|c|}
\hline Variable & Evaluation Item & Mean \\
\hline Psychology(4.125) & $\begin{array}{l}\text { I am very interested in leisure activities. } \\
\text { My leisure activities give me confidence. } \\
\text { My leisure activities give me a sense of } \\
\text { achievement. } \\
\text { I can use various skills and abilities in my } \\
\text { leisure activities. }\end{array}$ & $\begin{array}{l}4.2 \\
4.1 \\
4.2 \\
4.0\end{array}$ \\
\hline $\begin{array}{c}\text { Educational } \\
(3.95)\end{array}$ & $\begin{array}{l}\text { My leisure activities can enhance my } \\
\text { knowledge. } \\
\text { My leisure activities provide me the } \\
\text { opportunity to try new things. } \\
\text { My leisure activities help me understand } \\
\text { myself. } \\
\text { My leisure activities help me understand } \\
\text { others. }\end{array}$ & $\begin{array}{l}3.8 \\
4.1 \\
3.9 \\
4.0\end{array}$ \\
\hline Social(3.725) & $\begin{array}{l}\text { I interact socially with others through leisure } \\
\text { activities } \\
\text { My leisure activities help me make close } \\
\text { friends } \\
\text { The people I met during my leisure activities } \\
\text { are friendly. } \\
\text { In spare time, I often associate with those who } \\
\text { know how to enjoy leisure. }\end{array}$ & $\begin{array}{l}3.9 \\
3.7 \\
3.7 \\
3.6\end{array}$ \\
\hline $\begin{array}{c}\text { Relaxational } \\
(4.2)\end{array}$ & $\begin{array}{l}\text { My leisure activities help me relax physically } \\
\text { and mentally. } \\
\text { My leisure activities help me relieve stress. } \\
\text { My leisure activities contribute to my } \\
\text { emotional health. } \\
\text { I take part in leisure activities only because of } \\
\text { my own preference. }\end{array}$ & $\begin{array}{l}4.4 \\
4.4 \\
4.1 \\
3.9\end{array}$ \\
\hline physical(3.95) & $\begin{array}{l}\text { My leisure activities are challenging to my } \\
\text { physical strength. } \\
\text { My leisure activities can increase my physical } \\
\text { strength. } \\
\text { My leisure activities help me regain my } \\
\text { strength. } \\
\text { My leisure activities help me keep fit. }\end{array}$ & $\begin{array}{l}4.0 \\
3.9 \\
3.9 \\
4.0\end{array}$ \\
\hline Aesthetic(3.7) & $\begin{array}{l}\text { The place or area where I participate in leisure } \\
\text { activities is clean. } \\
\text { The place or area where I participate in leisure } \\
\text { activities is beautiful. } \\
\text { The place or area where I participate in leisure } \\
\text { activities is interesting. } \\
\text { The place or area where I participate in leisure } \\
\text { activities is well planned. }\end{array}$ & $\begin{array}{l}3.7 \\
3.8 \\
3.8 \\
3.5\end{array}$ \\
\hline
\end{tabular}

\section{The Analysis on Different Groups of Zhuhai Resident's}

\section{Leisure Satisfaction}

To conduct a further research of different variables (including gender, marital status, age, salary, education, family structure and residence) in six dimensions in Zhuhai citizen's leisure satisfaction, SPSS is employed in T-test (two groups) and One-Way ANOVA(more than two groups) to testify the difference of the mean whether variables will have striking influence on leisure activities. The results are as follows.

- Gender: Through the T-test of independent samples, the gender differences of Zhuhai people's leisure satisfaction are compared, which is displayed in table 3 . The result illustrates that female feel more satisfied than male in psychology, social contact and physiology, and less satisfied in education, relaxation and aesthetics. And it also indicates that female and male shares significant difference in psychological, social and aesthetic satisfaction.
- Marital Status: The same method is used to measure the influence of marital status on leisure satisfaction, which shows that married people feel a little bit more satisfied than unmarried one. The difference in five dimensions is slight, except in physiology.

- Age: Age consists of five groups. One-Way ANOVA is conducted to compare the mean of different groups. According to the statistical analysis, it indicates that there exists no obvious difference in different age groups, expect the group of more than 65 and the group of less than 25, who feel more satisfied.

- Income: There are six groups of salary. Expect the highest and lowest groups, the samples of the rest are similar. The statistical analysis shows the high salary group (more than 8000) feels less satisfied than the low salary group (less than 5000), especially in social, aesthetic and psychological dimensions.

- Education: The well-educated group's (above college education) satisfaction is slightly lower than poorly educated group (without college education), but the difference is not obvious.

- Family Size: The leisure satisfaction is not influenced by the size of family members. There is no predictable rule for all groups' satisfaction.

- Residence: No obvious differences of leisure satisfaction are shown in these three districts, but overall leisure satisfaction of Jinwan district is slightly higher than satisfaction of other two districts.

TABLE III. THE DIFFERENCE OF LEISURE SATISFACTION ON GENDER

\begin{tabular}{|l|l|l|l|l|l|}
\hline \multirow{2}{*}{ Variable } & \multicolumn{2}{|c|}{ female } & \multicolumn{2}{c|}{ male } & \multirow{2}{*}{ T } \\
\cline { 2 - 5 } & Mean & S.D. & Mean & S.D. & \\
\hline Psychological & 4.22 & 0.59 & 4.03 & 0.63 & $1.505^{*}$ \\
Educational & 3.92 & 0.55 & 3.98 & 3.73 & -0.511 \\
Social & 4.04 & 0.59 & 3.41 & 0.69 & $1.205^{* *}$ \\
Relaxational & 4.18 & 0.47 & 4.26 & 0.62 & -1.012 \\
Physiological & 3.98 & 0.61 & 3.92 & 0.664 & 0.843 \\
Aesthetic & 3.46 & 0.595 & 3.94 & 0.69 & $-1.343^{*}$ \\
\hline
\end{tabular}

\section{CONCLUSION}

The sense of well-being is not only the government's achievement, but also personal's life goal, which is the ultimate pursuit for both the government and the individual. This research demonstrates that the relativity between leisure satisfaction and happiness is closely correlated, and leisure satisfaction is the important index to measure the residents' happiness. Therefore, social welfare will be indirectly enhanced through the improvement of individual's happiness. This research, thereby, is valuable to the enhancement of the well-being, which is the focus of the government. Meanwhile, to compare different resident groups' attitudes towards leisure satisfaction, the research, taking demographic characteristics into account, indicates that such variables as gender, age, salary greatly influence leisure satisfaction, compared with such factors as marital status, education, family structure, and residence and so on. 
Compared with related researches abroad, the conclusions are incompatible. For instance, the researches made by Gökçe, Vong Tze,etc [10]-[16] prove that there is no obvious difference in gender in leisure satisfaction. Besides, no striking difference in income, according to Mancini, Samuel[17]-[18]. Therefore, more studies of case places should be compared, investigated and analyzed. Moreover, the researcher predicts that four variables, including marital status, education, family structure and residence, will affect leisure satisfaction, but the research in reality does not show any marked difference in analytical aspect, which, thereby, relies on a further large amount of samples.

\section{REFERENCES}

[1] Wessman,A.E. \&Ricks, D.F. (1966). Mood and Personality. New York: Holt,Rinehart and Winston.

[2] Andrews F.M., \& Withey, S.B. (1976). Social Indicators of wellbeing: America's Perception of Life Quality. New York: Plenum.

[3] Campbell, A., Converse, P. E.,\& Rodgers, W. L. (1976). The Quality of American Life: Perceptions, Evaluations, and Satisfactions. New York: Russell Sage Foundation.

[4] Russell, R. V (1996). Pastimes: the Context of Contemporary Leisure. Madison, WI: Brown \& Benchmark.

[5] Diener, E. (1994). Assessing Subjective Well-being: Progress and Opportunities. Journal of Social Indicators Research 31 (2): 421-475.

[6] Keyes, C. L. M. (1998). Social Well-being. Social Psychology Quarterly 88: 72-80.

[7] Beard JG, Ragheb MG (1980). Measuring leisure satisfaction. Journal of Leisure Research 1:20-33.

[8] Du Cap, M. C. (2002). The perceived impact of the Acadia Advantage Program on the leisure lifestyle and leisure satisfaction of the students at Acadia University (Master Thesis). Acadia University, Ottawa, Canada.

[9] Karlı, U., Polat, E., Yılmaz, B., \& Koçak, S. (2008). Reliability and validity study of Leisure Satisfaction Scale (LSS-Long Version). Hacettepe Journal of Sport Science, 19(2), 80-91.

[10] Gökçe, H. (2008). Examining of the leisure satisfaction with the relation between life satisfaction and socio-demographic variables (MasterThesis). Pamukkale University, Denizli, Turkey.

[11] Vong Tze, N. (2005). Leisure satisfaction and quality of life in Macao, China. Leisure Studies, 24(2), 195-207.

[12] Kabanoff, B. (1982). Occupational and sex differences in leisure needs and leisure satisfaction. Journal of Occupational Behavior, 3, 233-245.

[13] Boley, B. J. (2001). Life satisfaction, leisure satisfaction, and leisure participation among publicly housed older adults (Doctoral Thesis). Capella University, Minneapolis, USA.

[14] Broughton, K., \& Beggs, B. A. (2006). Leisure satisfaction of older adults. Activities, Adaptation \& Aging, 31(1), 1-18.

[15] Griffin, J., \& McKenna, K. (1998). Influences on leisure and life satisfaction of elderly people. Physical \& Occupational Therapy in Geriatrics, 15(4), 1-16.

[16] Ateca-Amestoy, V., Serrano-del-Rosal, R., \& Vera-Toscano, E. (2008). The leisure experience. The Journal of Socio- Economics, 37, 64-78.

[17] Mancini, J. A. (1978). Leisure satisfaction and psychologic wellbeing in old age: Effects of health and income. Journal of the American Geriatrics Society, 26(12), 550-552.

[18] Samuel, B. F. (2003). Perceived measure of women 50 to 65 years of age (Doctoral Thesis). Purdue University, USA. 